\title{
Modeling and Mapping Forest Fire Occurrence from Aboveground Carbon Density in Mexico
}

\author{
Carlos Ivan Briones-Herrera ${ }^{1}$, Daniel José Vega-Nieva ${ }^{1, *}$, Norma Angélica Monjarás-Vega ${ }^{1}$, \\ Favian Flores-Medina ${ }^{1}$, Pablito Marcelo Lopez-Serrano ${ }^{2}$, José Javier Corral-Rivas ${ }^{1} \mathbb{1}$, \\ Artemio Carrillo-Parra ${ }^{2}$, Miguel Ángel Pulgarin-Gámiz ${ }^{1}$, Ernesto Alvarado-Celestino ${ }^{3}{ }^{[0}$, \\ Armando González-Cabán ${ }^{4}$, Stéfano Arellano-Pérez ${ }^{5}{ }^{\circledR}$, Juan Gabriel Álvarez-González ${ }^{5}{ }^{\circledR}$, \\ Ana Daría Ruiz-González ${ }^{5}$ and William Mathew Jolly ${ }^{6}$ (i)
}

1 Facultad de Ciencias Forestales, Universidad Juárez del Estado de Durango, Río Papaloapan y Blvd, Durango S/N Col. Valle del Sur, 34120 Durango, Mexico; carlos.briones.ipi@gmail.com (C.I.B.-H.); normonjaras@gmail.com (N.A.M.-V.); maderas666@gmail.com (F.F.-M.); jcorral@ujed.mx (J.J.C.-R.); mpulgarin@ujed.mx (M.Á.P.-G.)

2 Instituto de Silvicultura e Industria de la madera, Universidad Juárez del Estado de Durango, Boulevard del Guadiana 501, Ciudad Universitaria, Torre de Investigación, 34120 Durango, Mexico; p_lopez@ujed.mx (P.M.L.-S.); acarrilloparra@ujed.mx (A.C.-P.)

3 School of Environmental and Forest Sciences, University of Washington, Mailbox 352100, University of Washington, Seattle, WA 98195, USA; alvarado@uw.edu

4 Pacific Southwest Research Station, US Department of Agriculture Forest Service, (retired), 4955 Canyon Crest Drive, Riverside, CA 92507, USA; carimbo@charter.net

5 Departamento de Ingeniería Agroforestal, Universidad de Santiago de Compostela, Escuela Politécnica Superior de Ingeniería, Campus Universitario s/n, 27002 Lugo, Spain; stefano.arellano@usc.es (S.A.-P.) juangabriel.alvarez@usc.es (J.G.Á.-G.); anadaria.ruiz@usc.es (A.D.R.-G.)

6 USDA Forest Service, Missoula Fire Sciences Laboratory, Missoula, MT 59808, USA; mjolly@fs.fed.us

* Correspondence: danieljvn@gmail.com; Tel.: +52-618-183-6804

Received: 3 April 2019; Accepted: 4 May 2019; Published: 9 May 2019

\begin{abstract}
Understanding the spatial patterns of fire occurrence is key for improved forest fires management, particularly under global change scenarios. Very few studies have attempted to relate satellite-based aboveground biomass maps of moderate spatial resolution to spatial fire occurrence under a variety of climatic and vegetation conditions. This study focuses on modeling and mapping fire occurrence based on fire suppression data from 2005-2015 from aboveground biomass-expressed as aboveground carbon density (AGCD)—for the main ecoregions in Mexico. Our results showed that at each ecoregion, unimodal or humped relationships were found between AGCD and fire occurrence, which might be explained by varying constraints of fuel and climate limitation to fire activity. Weibull equations successfully fitted the fire occurrence distributions from AGCD, with the lowest fit for the desert shrub-dominated north region that had the lowest number of observed fires. The models for predicting fire occurrence from AGCD were significantly different by region, with the exception of the temperate forest in the northwest and northeast regions that could be modeled with a single Weibull model. Our results suggest that AGCD could be used to estimate spatial fire occurrence maps; those estimates could be integrated into operational GIS tools for assistance in fire danger mapping and fire and fuel management decision-making. Further investigation of anthropogenic drivers of fire occurrence and fuel characteristics should be considered for improving the operational spatial planning of fire management. The modeling strategy presented here could be replicated in other countries or regions, based on remote-sensed measurements of aboveground biomass and fire activity or fire suppression records.
\end{abstract}

Keywords: aboveground biomass; ecoregions; fire occurrence 


\section{Introduction}

Forest fires have a cascade effect on the carbon cycle, directly through emissions [1,2] and indirectly through post-fire decomposition, soil impacts and change in productivity and post-fire vegetation trajectories with their associated subsequent $C$ sequestration abilities [3,4]. Therefore, land management and forest fire management, altering fuel properties and fire regimes, are considered key human instruments to influence the carbon cycle and buffer the climate change impact on fire regimes [5]. Climate change is projected to result in increased fire risk in various global ecosystems [6-8] and carbon storage in forests may help mitigate the future emission of greenhouse gases $[9,10]$ although the increase in biomass accumulation needs to be offset with the corresponding hazard increase [11]. Some studies have also suggested that the geographic distribution of wildfire might be altered by the increase in global temperature [12].

The biomass accumulation from reduced management of forests and fire exclusion could result in larger and more severe wildfires, resulting in greater losses of natural, economic and human resources $[3,13,14]$. Reducing biomass quantity and modifying their structure are the only physical parameter that humans can manage to reduce the adverse impacts of forest fires, including $C$ emissions [11,15-17].

Understanding the spatial distribution of fire occurrence is required to better quantify their environmental and economic impacts [18-20] and to improve strategic decision-making in fire management planning, including spatially explicit allocation of resources for fuel treatments and fire suppression strategies [21,22]. Wildfire occurrence has been associated with fuel types [23-25], forest species composition [20,26-28] and types of vegetation [29-34]. Some studies have related fire occurrence with tree cover [35], leaf area index [36], basal area [37], tree diameter at breast height [38], vegetation age [39] or other biometric characteristics [37,40].

Some of these studies, mainly at regional to national scales, have found that the occurrence of forest fires increases with increasing levels of basal area, shrubs load, or other biometric characteristics, (e.g., $[37,38]$ ), within their areas of study. On the other hand, other studies, in larger geographical areas of contrasting vegetation and climate, have proposed a non-linear relationship of fire occurrence with fuel availability under a varying constraints hypothesis, where fire can be limited by fuel or climatic conditions (e.g., [41-43]). Such studies have suggested that, in areas of more arid climate, fire occurrence is mainly limited by fuel availability and continuity. In contrast, in wetter areas such as tropical forests or temperate forests with higher precipitation, fire occurrence is generally limited by the effects of climate and tree cover on fuel moisture [35,41-47].

The effects of fuel availability on fire occurrence can largely vary both between climatic location or ecoregion $[35,42,43,45]$ and within those ecoregions (e.g., [46]). Some studies have compared average fire frequencies for contrasting ecoregions from regional and national [42,43] to global scales [48]. Those efforts have tested the general fire ecology hypothesis and provided valuable insights in understanding the link between fire regimes and ecosystem attributes, but those studies did not aim at analyzing the spatial variations in fire occurrence within those ecoregions. There is a need of improving the understanding of the relationship between forest biomass and fire occurrence within different climatic ecoregions in order to improve our forest and fire management planning.

Studies analyzing spatial relationships between fire occurrence and fuel availability, mostly at regional to global scales, have generally utilized coarse resolutions, often with pixels from $50-100 \mathrm{~km}$ (e.g., $[35,41])$. Whereas these regional to global maps are of great value for understanding large scale to global tendencies of fire activity distribution and its relationships with coarse scale indicators of fuel availability, they do not aim at supporting spatially explicit planning of fire and fuel management at finer scales. Very few studies have taken advantage of the existence of satellite products at finer resolutions, such as the study of Kahiu and Hanan [36], which related MODIS derived leaf area index [49] and fire activity at $1 \mathrm{~km}$ resolution. We are not aware of any study that has attempted to relate satellite-derived aboveground biomass maps with fire occurrence at $1 \mathrm{~km}$ resolution. 
Globally, the country of Mexico ranks highly among areas of the largest fire activity [50]. Mexico has experienced a marked increase in the fire weather season due to climatic change [7]. Furthermore, fire activity in the North American region is projected to increase under climate warnings [6]. Therefore, a detailed knowledge of the spatial distribution of fire occurrence is increasingly necessary in the country to inform strategic fuel and fire management planning decisions. Moreover, from the scientific perspective, Mexico provides an opportunity to analyze the variability of wildfire occurrence and explore potential relationships to biomass by ecoregion, because it hosts a wide range of vegetation types and climate, from arid deserts dominated by scrubby vegetation, temperate pine-oak forests and tropical forests [51], that results in a variety of fire regimes in the country [52-54].

Previous studies in Mexico have related fire occurrence with vegetation type, mainly at a local scale [55-57]. Some studies have documented differences in fire occurrence by ecoregion at a national level [58], but, in spite of medium resolution aboveground biomass or carbon density maps from satellite images being available at national $[59,60]$ and at local scales [61-64], no study has attempted to relate the spatial patterns of fire occurrence with aboveground biomass in Mexico.

The lack of an operational system for fire risk and danger mapping in Mexico, unlike countries like US or Canada [65-69], led to a national research project aiming at developing a fire danger forecast system for Mexico [70,71]. Previous studies have resulted in the development of temporal and spatial models for predicting the number and spatial distribution of wildfires from daily fuel dryness indices at $1 \mathrm{~km}$ resolution by vegetation types and regions in the country [72-74], but there is still no information on how these spatial patterns of fire occurrence might be affected by aboveground biomass within different vegetation types and ecoregions, limiting our knowledge of fire ecology in these variety of ecosystems and preventing the spatially explicit decision-making for fuel treatment and fire suppression strategic planning in Mexico.

The current study aimed at exploring relationships between aboveground biomass and fire occurrence for the main ecoregions of Mexico. The specific objectives of the study are: (i) To develop models for predicting the percentage of fire suppression records from aboveground biomass-expressed as carbon density-for the main ecoregions of Mexico; (ii) to map the expected percentage of fires by ecoregion from aboveground biomass for Mexico, at $1 \mathrm{~km}$ resolution.

\section{Materials and Methods}

\subsection{Study Area and Forest Regions}

The regionalization of the country was based on the regions proposed by [72], which was based on the North American ecoregions map (North American Level 3 Ecoregions Map, EPA, https://www.epa.gov/eco-research/ecoregions-north-america), together with previous analysis of the spatial patterns of fire occurrence in the country [70,75]. In addition, in this study we included two additional regions, north scrubland and chaparral, based on the land use map of the National Institute of Geography and Statistics (INEGI in Spanish, Land Use Map Series V, 1:250,000 http: //www.inegi.org.mx/geo/contenidos/recnat/usosuelo/) [51].

This resulted in a total of seven regions for analysis: CHAP: Chaparral forests; N: North scrubland forests; NW: Northwest forests; NE: Northeast forests; C: Center forests; SC: South-center forests and SE: Southeast tropical forests (Figure 1). Note that here the term "forest" is used in a broad sense. In fact, the chaparral and north forest comprise a mix of shrubby and wooded vegetation, the former being by far the dominant cover in both regions. 


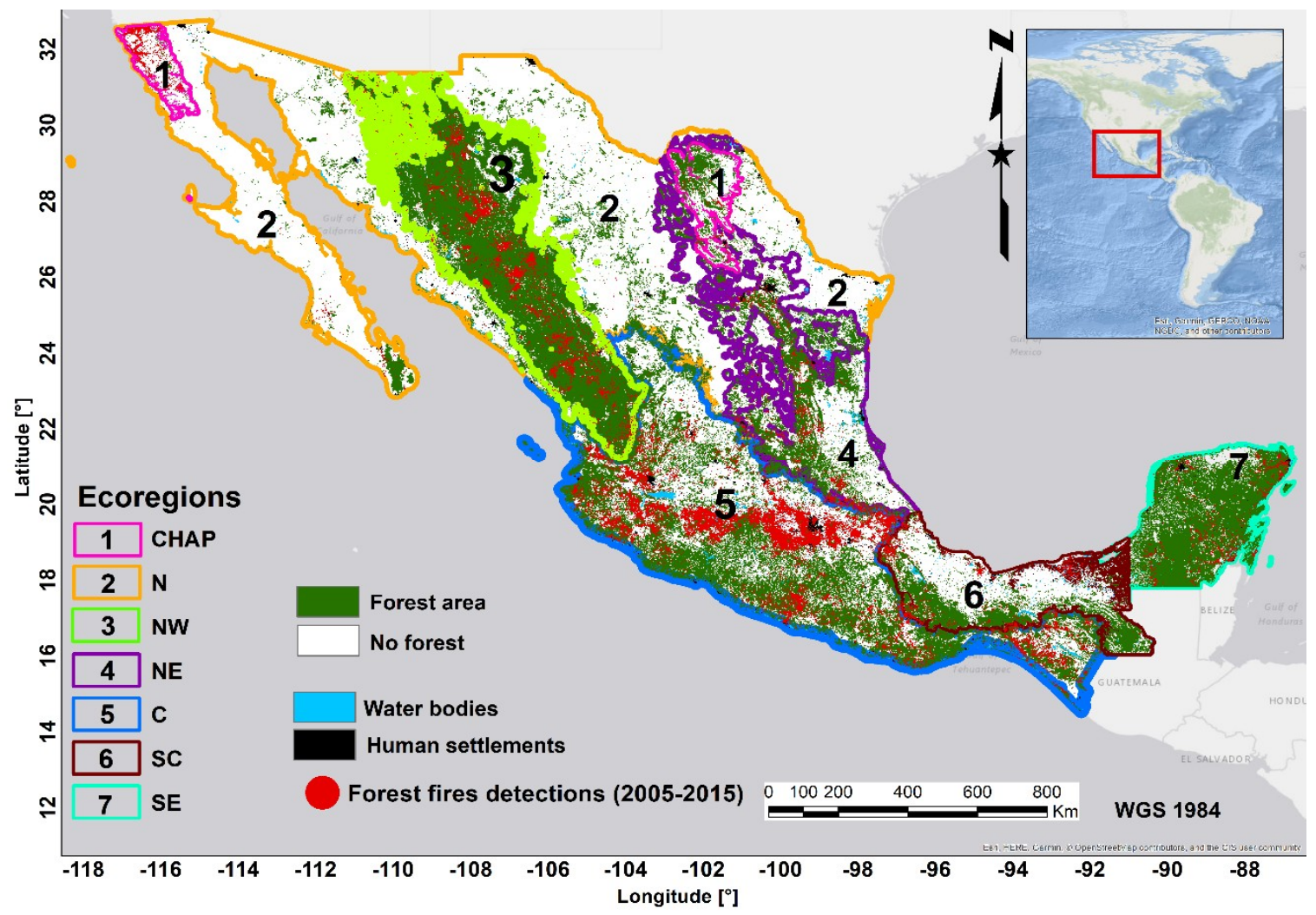

Figure 1. Map of ecoregions. Source: Modified from Vega-Nieva et al. [75] and considering National Institute of Geography and Statistics (INEGI) Land Use Map Series V (2011), 1:250,000 [51] where: CHAP: Chaparral forests; N: North forests; NW: Northwest forests; NE: Northeast forests; C: Center forests; SC: South-center forests; SE: Southeast tropical forests, respectively. Forest and no forest areas are shown in green and white, respectively; human settlements in black and water bodies in blue, respectively, according to INEGI Land Use Map Series V (2011), (1:250,000) [51]. Forest fires detections (2005-2015) represent the fire suppression records by Mexican Government Forest Agency (CONAFOR) in the period of study.

\subsection{Aboveground Carbon Density Data (AGCD)}

The aboveground carbon density map (AGCD) from the study of Cartus et al. [59] was utilized, because of its public availability. This map was obtained from Landsat images, radar data from ALOS PALSAR, calibrated with ground data of 16,906 plots from the Mexican National Forest and Soil inventory [62]. Species-specific biomass allometries and biomass to carbon conversion factors-ranging from 0.440 to 0.516 - were utilized [59].

The AGCD map was rescaled from $30 \times 30 \mathrm{~m}$ to $1000 \times 1000 \mathrm{~m}$ wall to wall for scale matching with the layers used in the ongoing Mexican Fire Danger System [70,72]. A low pass filter with a moving window of $3 \times 3$ pixels, using the package included in Spatial module of ERDAS IMAGINE 2014 software (ERDAS Inc., Atlanta, GA, USA), [76] was applied to the AGCD map.

\subsection{Forest Fire Data}

The fire suppression records database from the Mexican Government Forest Agency (CONAFOR) from the period 2005 to 2015 was utilized. The forest fires records in water bodies, cities and agriculture were excluded for the analysis based in the land use map from INEGI (2011) [51]. The database comprised a total of 53,000 fire suppression records in the period of study. 


\subsection{Observed Fire Occurrence by AGCD Calculation}

We firstly calculated the total number of forest fires, termed NFTi, for every region $i$. The aboveground carbon density (AGCD), in $\mathrm{MgC} \mathrm{ha}^{-1}$, was retrieved for every fire suppression record, using the extract multiple values to points tool in ArcGIS 10.1 software (ESRI: Redlands, CA, USA) [77] software.

For every forest region $(i)$, the fraction of fire occurrence recorded by AGCD value $(j)$ was calculated following Equation (1):

$$
\mathrm{FOB} i j=\mathrm{NF} i j / \mathrm{NF}_{T i}
$$

where: FOB: Fire occurrence index by biomass level (fraction of the number of fires recorded at a forest region $i$ for every AGCD value $j$ ); $\mathrm{NF}_{i j}=$ number of forest fires recorded a forest region $i$ for every AGCD value $j ; \mathrm{NF}_{\mathrm{T} i}=$ total number of forest fires recorded for the $i$ region.

\subsection{Modeling and Mapping Fire Occurrence from AGCD}

The two-parameters Weibull probability density function (PDF) model (Weibull, [78]) was tested to predict FOB from AGCD for every region following Equation (2):

$$
\mathrm{FOB}_{\mathrm{ij}}=\left(\frac{\mathrm{c}}{\mathrm{b}}\right) \cdot\left(\frac{\mathrm{AGCD}_{\mathrm{ij}}}{\mathrm{b}}\right)^{\mathrm{c}-1} \cdot \exp \left[-\left(\frac{\mathrm{AGCD}_{\mathrm{ij}}}{\mathrm{b}}\right)^{\mathrm{c}}\right]
$$

where: FOB: Fire occurrence index by biomass level at every forest region $i$ for every AGCD value $j$ (Equation (1)); AGCD is the observed aboveground carbon density value $j$ for every $i$ region; and $b$ and $c$ are the scale and the shape parameters of the model coefficients to be estimated, respectively.

The Weibull model was selected based on visual inspection of the data distributions. This function has been widely applied (e.g., [79-83]) because of its flexibility to capture different shapes of distributions together with its relative simplicity. The models to predict observed FOB from AGCD (Equation (2)) were fitted with non-linear regression (NLS) using the package "nls" of the software R (R Core Team, Vienna, Austria [84]).

In addition, the nonlinear extra sum of squares method (Bates and Watts, [85], pp. 103-104) was used to assess whether the models were significantly different among different regions. This method has often been utilized to assess whether separate models are necessary for different species or different geographic regions (e.g., [73,86-88]). It involves the fitting of full and reduced models. The reduced model corresponds to the same set of global parameters in the function (Equation (2)) for all regions. In the full models, different sets of global parameters are tested for different regions. This is tested by expanding each global parameter in Equation (2) by including an associated parameter and a dummy variable to differentiate the region.

For example, the expansion of a global parameter c of Equation (2) can be written as Equation (3):

$$
\mathrm{c} 1 \mathrm{~d} 1+\ldots+\mathrm{c} 7 \mathrm{~d} 7
$$

where: $\mathrm{c} 1-\mathrm{c} 7$ are the associated parameters of the full model (Equation (2)) for each of the seven regions, and $\mathrm{d} 1-\mathrm{d} 7$ are the dummy categorical variables for considering the regions, which are defined as follows: $\mathrm{d} 1=1$ if region $=$ region 1 , otherwise $\mathrm{d} 1=0 ; \ldots ; \mathrm{d} 7=1$ if region $=$ region 7 , otherwise $\mathrm{d} 7=0$;

The non-linear extra sum of squares follows an $F$ distribution. We selected candidate models where the grouped coefficients were significantly different as detected by the $F$-test $(p<0.05)$.

Since the goal of our study was to evaluate the goodness-of-fit of Weibull distributions utilized as regression models, standard tests often used to evaluate the performance of probability distribution functions (e.g., Kolmogorov-Smirnov, Cramear-von Mises and Andersen-Darling tests) were not used. Such tests were not designed to answer questions about the error associated with predictions obtained from a regression model (e.g., [89-91]), which was the goal of our analysis. 
Candidate models were evaluated using the coefficient of determination for nonlinear regression $\left(R^{2}\right)$ as a statistical criterion, together with root mean square error (RMSE) and model bias. $R^{2}$ is defined as the square correlation coefficient between the measured and estimated values and the root mean square error (RMSE) [92]. In addition, we considered the simultaneous $F$-test for intercept $=0$ and slope $=1$ [93], to evaluate the goodness-of-fit of the Weibull models.

The predicted FOB values were normalized from 0 to 100, scaling by the maximum predicted value for every region. Normalized predicted FOB (FOBN) was mapped for the whole country using ArcGIS 10.1software (ESRI: Redlands, CA, USA) [77].

\section{Results}

For the period of study (2005-2015), the Center region had the largest number of fires, with an $\mathrm{NFT}_{\mathrm{i}}$ of 13,220 fire suppression records, equivalent to a fire density of 395 fires per 10,000 $\mathrm{km}^{2}$ of forest land. The lowest fire density was observed in the arid North region, with only 91 fires in the 10 years of the period of study, equivalent to a fire density of eight fires per $10,000 \mathrm{~km}^{2}$.

The estimates and the confidence interval of the Weibull PDF parameters and the values of the goodness-of-fit statistics for each region are shown in Table 1. The results of the nonlinear extra sum of squares method showed that all models were significantly different between regions, with the exception of NW and NE regions, which could be explained with a common set of parameters because of the absence of significant differences between these two temperate-forest dominated regions. Therefore, these two regions (NW and NE) were considered as a unique unit.

Table 1. Coefficients and goodness-of-fit statistics of the best models for predicting fire occurrence index by biomass level (FOB).

\begin{tabular}{cccccc}
\hline \multirow{2}{*}{ Ecoregions } & \multicolumn{2}{c}{ Coefficients } & \multicolumn{4}{c}{ Goodness of Fit } \\
\cline { 2 - 6 } & $\mathbf{b}$ & $\mathbf{c}$ & $\mathbf{R}^{\mathbf{2}}$ & RMSE & Bias \\
\hline CHAP & $21.45( \pm 0.83)$ & $1.97( \pm 0.12)$ & 0.715 & 0.008 & 0.0011 \\
N & $17.85( \pm 0.88)$ & $3.81( \pm 0.55)$ & 0.487 & 0.029 & 0.0045 \\
NW_NE & $27.22( \pm 0.16)$ & $3.63( \pm 0.06)$ & 0.980 & 0.002 & $0.1 \times 10^{-5}$ \\
C & $33.12( \pm 0.30)$ & $3.02( \pm 0.07)$ & 0.953 & 0.003 & $0.1 \times 10^{-4}$ \\
SC & $25.85( \pm 0.80)$ & $2.53( \pm 0.16)$ & 0.720 & 0.008 & 0.0002 \\
SE & $31.34( \pm 0.57)$ & $2.69( \pm 0.11)$ & 0.839 & 0.005 & 0.0011 \\
\hline
\end{tabular}

Where: CHAP: Chaparral forests; N: North scrubland forests; NW-NE: Northwest and northeast forests; C: Center forests; SC: South-center forests; SE: Southeast tropical forests; $b$ and $c$ are the estimates of the two-parameters Weibull probability density function (PDF) fitted for prediction of FOB from aboveground carbon density (AGCD) (confidence interval in brackets); $\mathrm{R}^{2}$ : Coefficient of determination; RMSE: Mean square error (in FOB units); bias: Model bias (in FOB units).

The scale parameter of the two-parameters Weibull PDF $(b)$ which influences the AGCD value at which the maximum FOB is predicted, varied from 17 to 33. The lowest predicted values of $b$ coefficient were obtained for North scrubland (N) and chaparral (CHAP) regions, with values of 17 and 21, followed by South-center (SC), Northeast (NE) and Northwest (NW), with $b$ values ranging from 25 to 29 . The highest $b$ values were obtained for $\mathrm{SE}$ and $\mathrm{C}$ regions, with values of 31 and 33 , respectively. The parameter $c$ is related to the shape of the two-parameters Weibull PDF, with higher values meaning steeper distributions result in FOB values focused on a narrower range of AGCD values. The highest values of $c$ coefficient (steeper distributions) in the range 3.6-3.8, were observed for the regions of the $\mathrm{NW}-\mathrm{NE}$ and $\mathrm{N}$ forests. Lower c values (flatter distributions) of around 2.5, were obtained for the SC and SE forest and the lowest $c$ coefficient values (1.9) were obtained for the CHAP region.

The best goodness-of-fit statistics were obtained for the C and NW-NE regions with $\mathrm{R}^{2}$ values of 0.95 and 0.98 , respectively and RMSE values of 0.002 and 0.003 , respectively. The lowest values of the goodness-of-fit statistics were obtained for the $\mathrm{N}$ region with a $\mathrm{R}^{2}$ and RMSE of 0.48 and 0.029 , respectively (Table 1). These goodness-of-fits are similar to or higher than the range of $R^{2}$ of 
0.5-0.7 reported in the literature for spatial analysis of fuel availability and fire activity (e.g., [35,41]). Nevertheless, the fuel-related variables utilized in those studies-leaf area index, tree cover, among others, the size of the area of study, and the pixel size in the case of global analysis, are not directly comparable to the approach and spatial resolution utilized in the current study.

The curve of observed fire occurrence by biomass level FOB for each forest region is shown in Figure 2, together with the predicted values, against AGCD. In the chaparral and North scrubland forests (Figure 2a,b) the highest values of FOB occurred at low values of AGCD (from 7 to 25, 10 to $22 \mathrm{Mg} \mathrm{C} \mathrm{ha}^{-1}$, respectively).
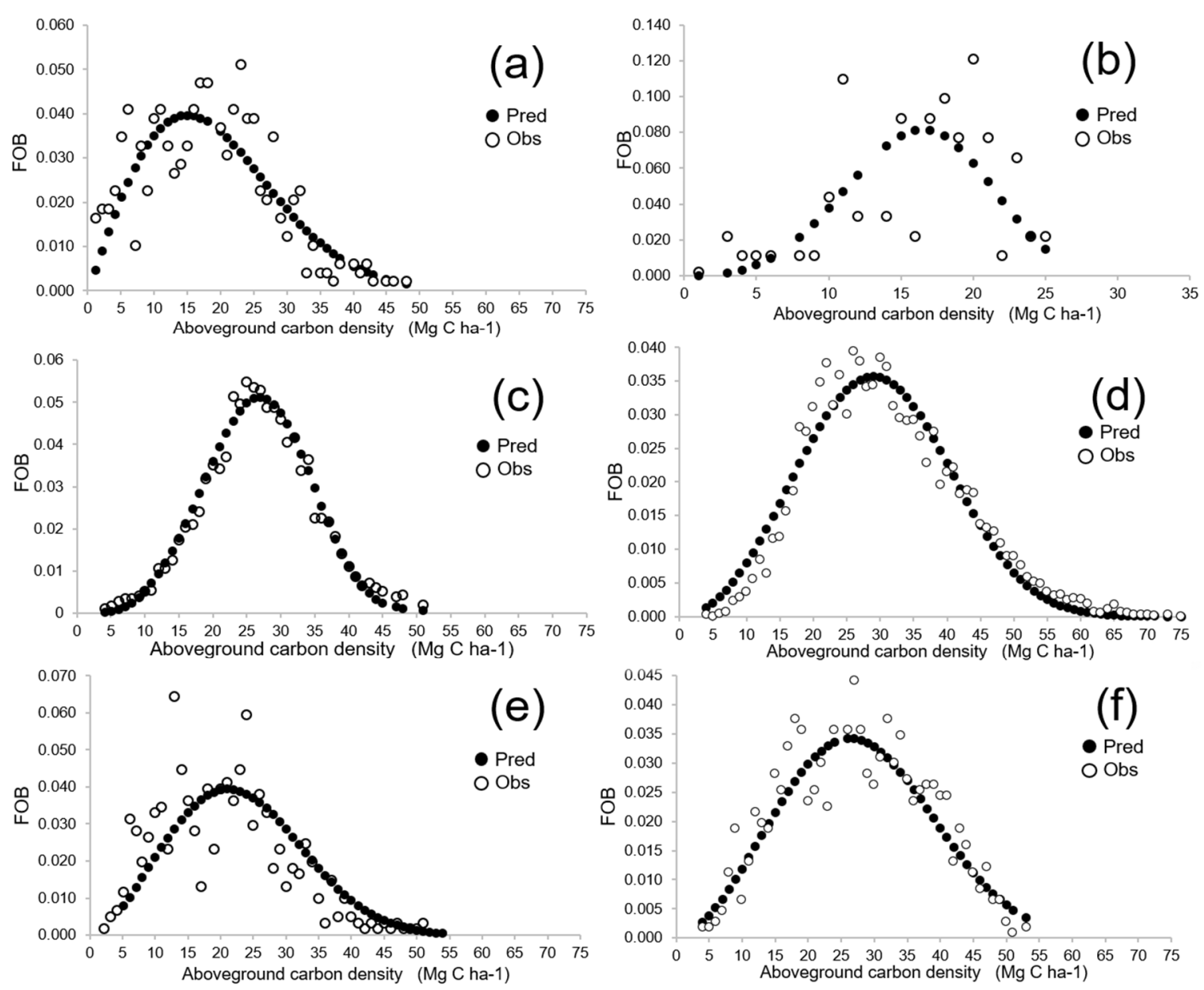

Figure 2. Predicted and observed fire occurrence by biomass level (FOB) against aboveground carbon density (AGCD) $\left(\mathrm{Mg} \mathrm{C} \mathrm{ha}^{-1}\right)$ for each region CHAP (a); N (b); NW and NE (c); C (d); SC (e) and SE (f); Pred: Predicted values; Obs: Observed values.

For the regions of the combined Northwest, Northeast and South-centre (Figure 2c,e), highest values of FOB were related with medium values of AGCD (from 15 to $35 \mathrm{Mg} \mathrm{C}^{-1}$ ), with a steeper distribution for the NW and NE compared to SC.

In the Center and Southeast regions, (Figure 2d,f), the highest FOB values were observed in slightly higher AGCD values, ranging from 20-22 to $35 \mathrm{Mg} \mathrm{C} \mathrm{ha}^{-1}$, with a flatter distribution for SE. Lower fire occurrence was observed at the highest biomass levels for all regions.

Predicted against observed FOB values and the related goodness-of-fits statistics are shown in Figure 3. The results of the simultaneous F-test (Figure 3) show that there are no reasons to reject the null-hypothesis of intercept $=0$ and slope $=1$ meaning that there are no systematic over or underestimates in any ecoregion. The map of predicted FOB for Mexico based on the fitted models is 
shown in Figure 4. A good agreement can be seen between predicted FOB values mapped and the historical fire suppression records spatial distribution in the country.
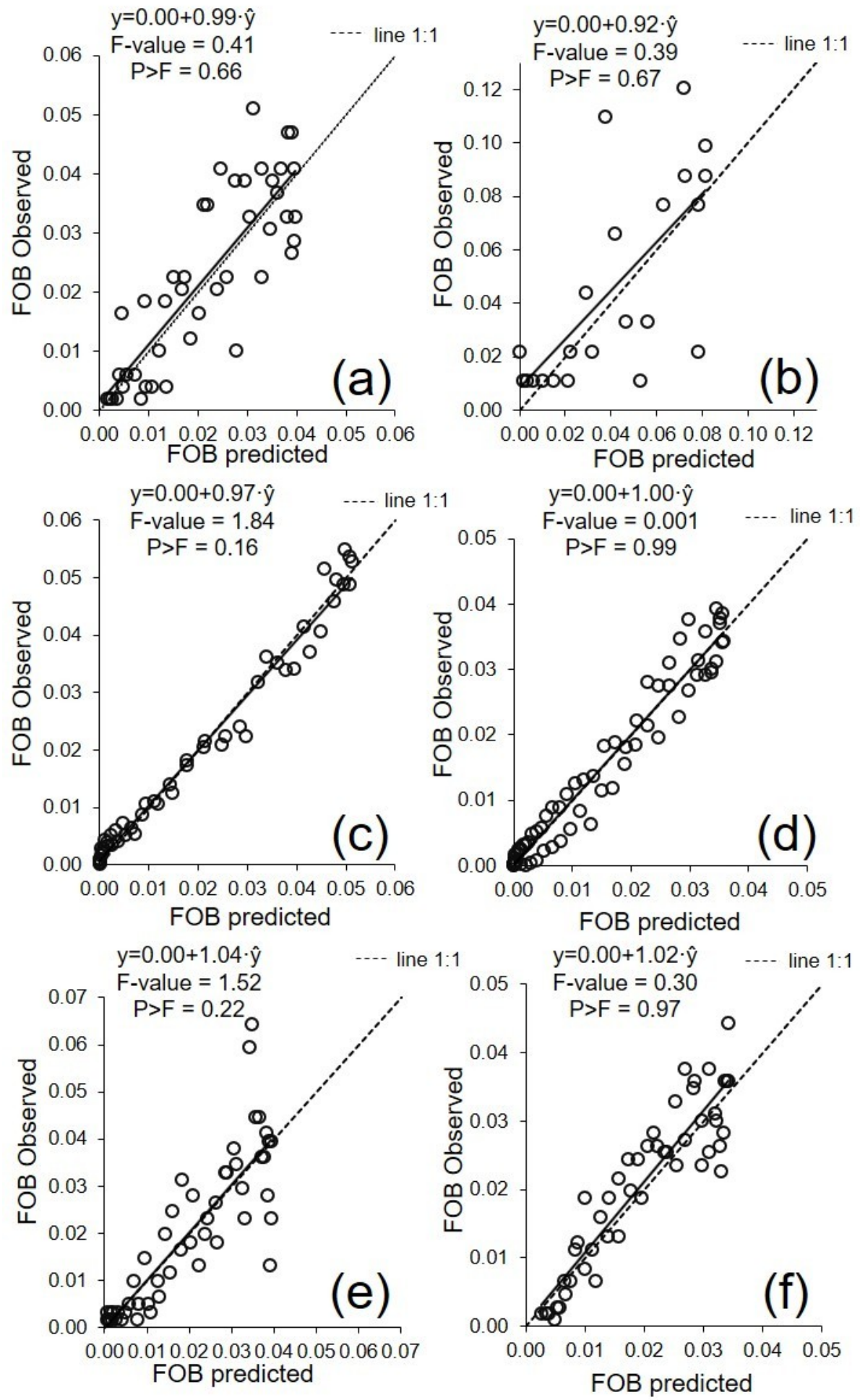

Figure 3. Predicted against observed fire occurrence by biomass level (FOB) for the regions CHAP (a); $\mathrm{N}(\mathbf{b}) ; \mathrm{NW}$ and NE(c); C (d); SC (e) and SE (f). F-values and probabilities $(p>F)$ correspond to the simultaneous $F$-test for intercept $=0$ and slope $=1$. Dotted lines represent the 1:1 line and full lines represent the observed $(y)$ against predicted $(\hat{y})$ FOB linear regression lines. 


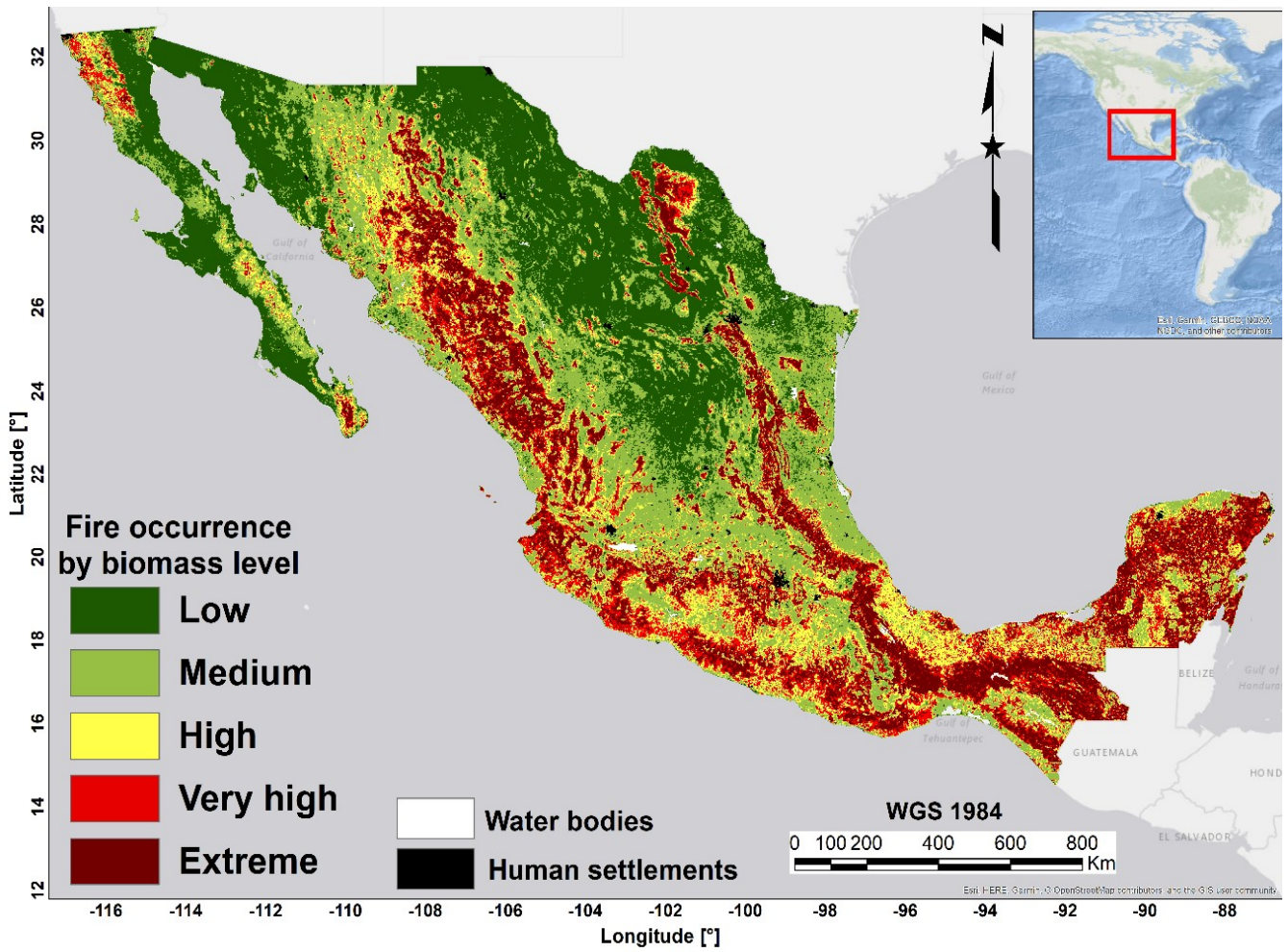

(a)

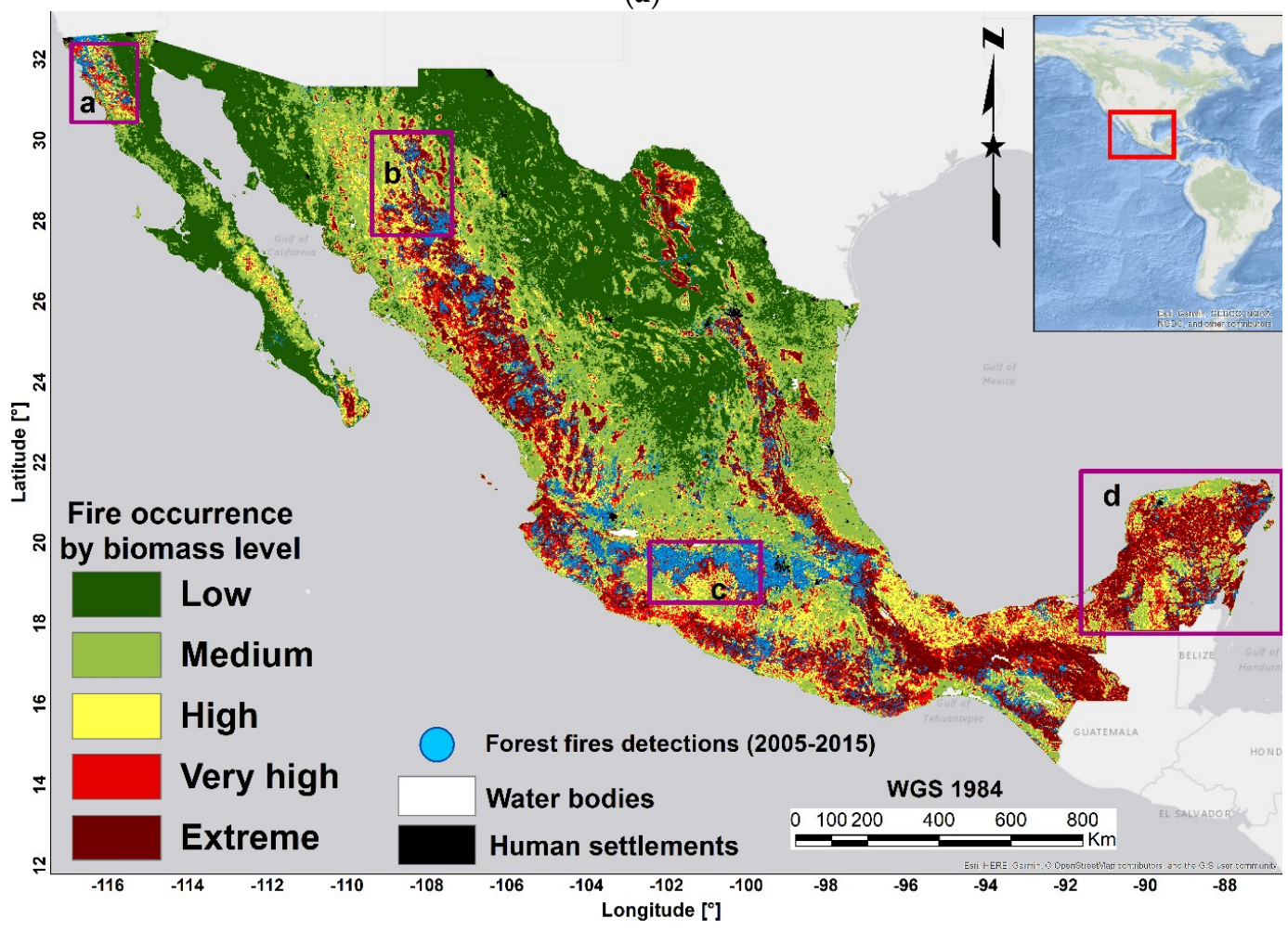

(b)

Figure 4. (a) Map of normalized fire occurrence by biomass level ( $\left.\mathrm{FOB}_{\mathrm{N}}\right)$; where low, medium, high, very high and extreme represent $\mathrm{FOB}_{\mathrm{N}}$ values of $<1 \%, 1 \%-25 \%, 25 \%-50 \%, 50 \%-75 \%$ and $>75 \%$ respectively. (b) Location of suppressed fires in the study period. The three regional detailed windows included in Figure $4 \mathrm{~b}$ are analyzed in detail in Figure 5. 


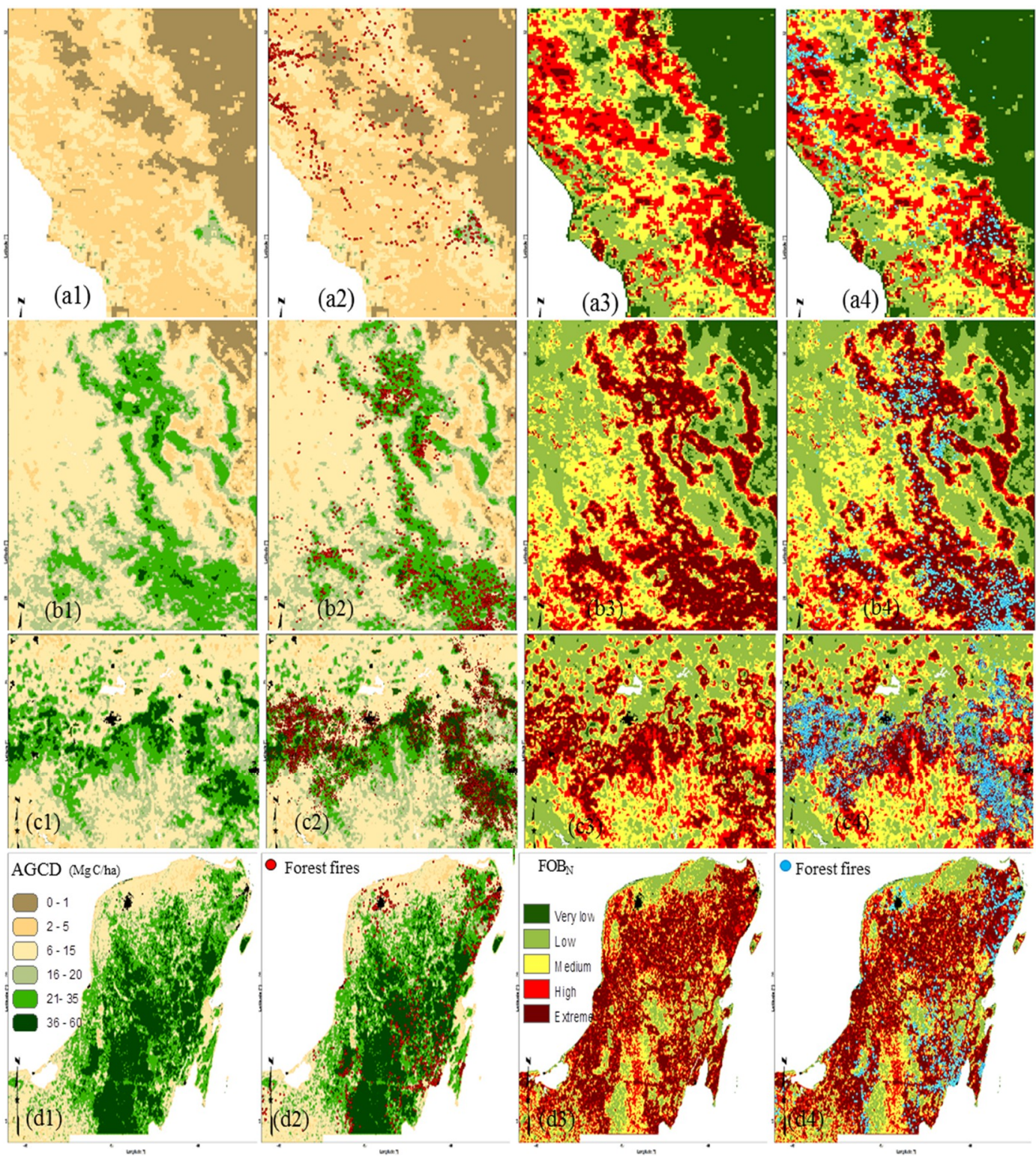

Figure 5. Detailed examples of aboveground carbon density (AGCD, $\mathrm{Mg} \mathrm{C} \mathrm{ha}^{-1}$ ) and normalized fire occurrence by biomass level $\left(\mathrm{FOB}_{\mathrm{N}}\right)$ for regions: $\mathrm{CHAP}$ and $\mathrm{N}(\mathbf{a})$; NW and $\mathrm{NE}(\mathbf{b}) ; \mathrm{C}$ (c) and SC and SE (d). Left panels (1) show observed AGCD $\left(\mathrm{Mg} \mathrm{C} \mathrm{ha}^{-1}\right)$, together with observed forest fire suppression records in red (2). Right panels show predicted $\mathrm{FOB}_{\mathrm{N}}$ (3) together with observed forest fire suppression records in blue (4).

Selected regional detailed examples of the mapped $\mathrm{FOB}_{\mathrm{N}}$ are shown in Figure 5. In the case of the chaparral forests, higher FOB values were observed in sites with low levels of AGCD (5 to 20, Mg C $\mathrm{ha}^{-1}$ ) (Figure 5a), for which maximum fire occurrence was predicted (Figure 5a, right figures). In the Northwest and Northeast forests (Figure $5 b$ ), highest fire occurrence was predicted for intermediate levels of AGCD (from 15 to $35 \mathrm{Mg} \mathrm{Cha}{ }^{-1}$ ), with lower values of FOB for the highest AGCD values $\left(>35 \mathrm{MgC} \mathrm{ha}^{-1}\right.$ ). In the $\mathrm{C}$ and Southeast forests (Figure $5 \mathrm{c}, \mathrm{d}$ ), highest FOB values were observed in intermediate levels of 20 to $35 \mathrm{MgC} \mathrm{ha}^{-1}$ and lower fire occurrence was also observed at the highest biomass ( $>35 \mathrm{MgC} \mathrm{ha}^{-1}$ ). 


\section{Discussion}

The varying relationships of AGCD with fire occurrence by region agree with studies that have found different effects of fuel availability on fire activity by climatic regions (e.g., [41-43]). At each ecoregion, biomass effects on fire activity might vary because of the interactions of climate and fuel availability on fire occurrence (e.g., [35,44-47,49]).

For the chaparral region, (Figures 2a and 5a), a large percentage of fire suppression records occurred at AGCD values in the range $5-25 \mathrm{MgC} \mathrm{ha}^{-1}$, with the highest values of fire occurrence found in the range $15-25 \mathrm{Mg} \mathrm{C}^{-1}$, approximately corresponding to fuel loads from 30 to $50 \mathrm{Mg}$ $\mathrm{ha}^{-1}$. The latter figure is likely the upper limit for fuel load in this type of vegetation in Baja California, where due to lower fire rotation periods than in a similar vegetation type in Southern California [94], fuel load is probably lower than in the latter region $[95,96]$. This suggests that fire suppression in this region seems to have mainly focused on areas with the highest chaparral fuel load and continuity, where fire spread is expected to be more frequent and dangerous [39,97-99].

In contrast, in areas of low biomass, in spite of dry climate and the associated low dead fuel moisture, fire spread is probably limited by low fuel availability like in other Mediterranean shrubby areas. Reduction in fire occurrence in the latter areas has been attributed to changes in fuel load, structure and connectivity (e.g., [100]).

The relatively lower number of recorded fires in the highest AGCD values in this chaparral ecoregion seems to be associated to the pine-oak "sky islands" forests, which accumulate comparatively higher biomass values than the genuine shrubby chaparral-dominated areas. This is consistent with observations in Mediterranean landscapes where fire occurrence is also higher on scrublands than in wooded areas $[29,30,101]$.

There are further factors that should also be considered in future research to explain the spatial patterns of fire occurrence in chaparral regions. For example, Vega-Nieva et al. [71] and Monjarás-Vega et al. [102] suggest that the spatial pattern of ignitions in the chaparral area is very strongly influenced by anthropogenic factors such as by vicinity of roads and urban areas, which are related to accessibility for human ignition and also for allowing access for fire suppression. This vicinity of ignitions to human settlements in the Baja California chaparral area might be linked to recent urban growth, and its associated wildland-urban interface, similarly to that reported by Syphard et al. [103] on the adjacent Southern California.

Unlike the chaparral region, temperate pine and oak forests in the NW, NE (Figures $2 c$ and $5 b$ ) and $\mathrm{C}$ regions (Figures 2e and 5c) did not experience a large fire occurrence for AGCD $<15 \mathrm{Mg} C$ $\mathrm{ha}^{-1}$. In these regions, low biomass areas are mainly covered by xerophytic scrublands [51] which, unlike chaparral, are characterized by lower fuel continuity and generally lower fire propagation hazard $[53,54]$. The lower occurrence of fires observed in these low biomass semi-desert and desert shrublands, compared to forested areas, has been previously reported in these regions in Mexico [55-58]. This also is in line with observations in other countries where lower fire occurrence in desert scrubland areas has been related to lower fuel load and continuity, limited by the extremely dry climate $[47,100]$.

Several reasons might explain the highest fire occurrence found at intermediate levels of AGCD (15-35 Mg C ha-1) in the above-mentioned temperate forest ecosystems. Intermediate biomass is associated to areas dominated by woody secondary vegetation. This primarily consists of young trees stands with low crown base height and bearing high loads of surface fuels that result in potentially more intense fires, including torching $[53,54]$. This agrees with very high occurrence of MODIS active fires observed in the secondary vegetation, classified as a very hazardous fire-prone vegetation type by Vega-Nieva et al. [73]. Likewise, with observed increases in fuel availability and fire spread potential related to decreasing tree cover in other countries $[36,42,104]$. On the other extreme within those temperate forests, the highest biomass areas, with lower fire occurrence, correspond to dense old-growth forests, mainly located from middle to high elevations. These stands, with moderate to high basal area, consist of tall dominant mature trees with high crown base height. This fuel structure limits wind penetration and sunlight incidence, maintaining low surface fuel loads and microclimatic 
and fuel structural conditions that hamper the occurrence of high severity fires [105]. This would explain the higher resilience to fire of these ecosystems, adapted to low severity natural fires, thus enabling the maintenance of ecosystem's health and self-regulating surface loads at levels that prevent catastrophic large severe fires $[16,106,107]$.

Finally, the response of fire occurrence in tropical SE forests to forest biomass might be partially explained by taking into account differences in forest structure, microclimatic conditions and human influences on ignition. Thus, the highest fire occurrence observed in the intermediate biomass levels corresponds to the dry and seasonally dry tropical forest, as opposed to lower fire occurrence in the high biomass areas associated to the evergreen wet tropical forests, where high fuel moisture throughout the year limits fire occurrence [52,53,71,72]. Areas of highest biomass and tree cover tend to be fire-limited by fuel moisture with wet fuels preventing ignition, together with a lower fire spread potential $[36,42,43,108]$.

At the same time, in tropical forests, lower biomass areas are more connected to active forest degradation at landscape level, including slash and burn activities, which are important causes of fire occurrence in the SE region $[55,56,109,110]$. An example of the evident role of human accessibility in fire occurrence in these wet tropical ecosystems can be found in Ressl et al. [111]. In that study, the majority of ignitions in the Kalakmul reserve (south of the Yucatan Peninsula) were located in the vicinity of roads, whereas most isolated areas had an extremely small number of ignitions, very possibly because of the difficulties in accessing inside this very dense type of tropical forest. Posterior observations of human factors of fire occurrence for the whole Yucatan Peninsula [71,102] confirm the same pattern. This strongly suggests the need for considering anthropogenic factors in combination with biomass and fuel dryness [73] to gain insight into the multiple interactions behind the spatial distribution of fire occurrence and improve our ability of fire occurrence prediction.

Overall, our results suggest a gradient in the AGCD values for the respective maximum fire occurrence in the observed FOB distributions from the driest ( $\mathrm{N}$ and $\mathrm{CHAP}$, with peaks of FOB at $<20 \mathrm{Mg} \mathrm{C} \mathrm{ha}{ }^{-1}$ ) to the wettest ecoregions ( $\mathrm{C}$ and SE, with maximum FOB at $>30 \mathrm{Mg} \mathrm{C}^{-1}$ ), with intermediate FOB peaks (between 25 and $30 \mathrm{Mg} \mathrm{C} \mathrm{ha}^{-1}$ ) for the temperate forests of the NE and NW regions. These variations in the shape and maximum values of FOB across climatic gradients of aridity resemble the general tendency hypothesized by Dohn et al. [112] and Kahiu and Hanan [36] (Figure 2b), among others, relating tree cover and precipitation gradients with fire activity. Unlike the latter study [36], which utilized a MODIS leaf area index for explaining fire activity, our study related the variations in the relationships between aboveground biomass and fire occurrence at $1 \mathrm{~km}$ for contrasting climatic ecoregions, suggesting potential of biomass maps as explanatory variables to aid in fire occurrence modeling at operational scales for fire management planning.

Whereas these differences between the peaks and distribution shapes of fire occurrence between the arid N, temperate NW and NE and more humid C and SE regions seem to confirm a gradient in the AGCD values of maximum fire occurrence, one exception would be the very rainy SC region, where the highest fire occurrence would be expected at higher AGCD values, similar to the rainy tropical $\mathrm{SE}$ region, or to the $\mathrm{C}$ region. We speculate that other factors in addition to climate, such as lower road accessibility and urban areas density, might result in these areas being less accessible for ignition in the SC. That contrasts with higher road and urban areas density of the $\mathrm{C}$ region that might result in a higher percentage of fires occurring at higher biomass values in this densely populated region. Further research in the combined role of biomass and human factors in explaining fire occurrence spatial patterns by region might clarify these potential interactions.

The number of ecoregions utilized offered a good compromise between having contrasted climatic and vegetation conditions and containing enough internal variability in aboveground biomass to allow the finding of significant relationships with a representative number of fire suppression records. One exception would be the desert shrubby $\mathrm{N}$ region, which is characterized by rare fire activity. Longer periods of observation would be required for improving these initial models in this region. 
In addition, future work might explore a finer regionalization to account for further internal variability within ecoregions.

Combining these data about the most likely locations where fire may occur based on region-specific AGCD relationships, with other information about road densities and urban locations-which also affect spatial patterns of fire ignitions [71,102], better maps of wildfire ignition likelihood could be produced. These ignition likelihood maps could be combined with weather-driven metrics to create improved spatial estimates of wildfire risk across Mexico that would provide better decision support information for forest and fire managers.

\section{Conclusions}

The current study presents the first available map for fire occurrence based on aboveground carbon density in Mexico. The results support the hypothesis of fuel limitation-which explains a substantial part of fire occurrence in the most arid regions-and climate limitation for the wetter regions. The maximum values of fire occurrence occurred at different aboveground carbon density values by region, with the most arid regions (chaparral and $\mathrm{N}$ desert shrubs) at values of $<20 \mathrm{Mg} \mathrm{Cha}^{-1}$, and the wetter regions $\mathrm{C}$ and $\mathrm{SE}$ at $>30 \mathrm{Mg} \mathrm{C} \mathrm{ha}^{-1}$. Whereas these first models help improve our understanding of the spatial pattern of fire occurrence in Mexico, the complexity of the phenomenon of fire occurrence demands to explore additional variables likely affecting these patterns.

Variations in fuel complex load and other structural attributes, associated to climate and tree cover differences, combined with other additional factors, not still quantified, such as anthropogenic drivers are probably influencing fire occurrence and they deserve further study. The role of humans and infrastructure-related variables such as distance to roads, human settlements, level of agricultural activities and the presence of respective interfaces with forest on the spatial patterns of fire occurrence needs to be explored in future studies.

Although the study period is not very large, it comprised dry and wet years and appears sufficiently representative to have a good picture of the situation for most of the ecoregions. Nevertheless, given the very low fire occurrence in the 10-year study period for the shrubby vegetation in the $\mathrm{N}$ region, a longer period of observation will be required to improve these first models in this region.

The successful use of the Weibull model to predict the observed fire occurrence distributions as a function of the total aboveground biomass was likely due to the latter acting as a proxy of fuel load and other fuel structural features $[113,114]$ connected with fire flammability, a point that needs to be further investigated. Still, it would be desirable for future studies to utilize a fuel characteristics map, once such map becomes available nationally. Additionally, the latter would assist to better understand the connection between fire occurrence and fuel structure and connectivity at landscape scale.

Given the reasonably good predictive ability of most of the eco-regional models to estimate fire occurrence from AGCD, the quantitative approach developed can be included in operational GIS tools for assistance in fuel treatment prioritizing and suppression resources allocation decision-making at a national scale. These first models could be improved in the future with larger datasets, and the inclusion of fuel characteristics and human factors.

The modeling strategy presented here could be replicated in any other country or region, based on satellite measures of aboveground biomass and satellite measurements of fire activity or fire suppression records, for analyzing patterns of fire occurrence under contrasting climates, vegetation types, and human patterns of ignition.

Author Contributions: Conceptualization, C.I.B.-H. and D.J.V.-N.; formal analysis, C.I.B.-H., N.A.M.-V. and F.F.-M.; methodology, D.J.V.-N., P.M.L.-S. and J.J.C.-R.; writing一original draft, C.I.B.-H. and D.J.V.-N.; writing-review and editing, A.C.-P., M.Á.P.-G., E.A.-C., A.G.-C., S.A.-P., J.G.Á.-G., A.D.R.-G. and W.M.J.

Funding: Funding for this work was provided by CONAFOR/CONACYT Projects "CO2-2014-3-252620" and "CO-2018-2-A3-S-131553" for the development and enhancement of a Forest Fire Danger Prediction System for Mexico. The scholarships from CONACYT for Carlos Briones to study a Masters program in Forest Sciences at the Universidad Juarez del Estado de Durango and to fund a research stay at the University of Santiago de Compostela (Spain) is also acknowledged. 
Acknowledgments: We want to thank CONAFOR's personnel, in particular Eduardo Cruz Castañaeda, Alfredo Nolasco, Yucundo Coutiño Estrada, Cesar Robles and Abner Jimenez Flores, for their support to the current study and for providing the fire suppression database for Mexico utilized in the period of study of this work.

Conflicts of Interest: The authors declare no conflict of interest. The founding sponsors had no role in the design of the study; in the collection, analyses, or interpretation of data; in the writing of the manuscript, and in the decision to publish the results.

\section{References}

1. North, M.; Hurteau, M.; Innes, J. Fire suppression and fuels treatment effects on mixed-conifer carbon stocks and emissions. Ecol. Appl. 2009, 19, 1385-1396. [CrossRef] [PubMed]

2. Van der Werf, G.R.; Randerson, J.T.; Giglio, L.; Collatz, G.J.; Mu, M.; Kasibhatla, P.S.; Morton, D.C.; De Fries, R.S.; Jin, Y.; van Leeuwen, T.T. Global fire emissions and the contribution of deforestation, savanna, forest, agricultural, and peat fires (1997-2009). Atmos. Chem. Phys. 2010, 10, 11707-11735. [CrossRef]

3. Bowman, D.M.; Balch, J.; Artaxo, P.; Bond, W.J.; Cochrane, M.A.; D'Antonio, C.M.; DeFries, R.; Johnston, F.H.; Keeley, J.E.; Krawchuk, M.A.; et al. The human dimension of fire regimes on Earth. J. Biogeogr. 2011, 38, 2223-2236. [CrossRef]

4. Liu, Y.; Goodrick, S.L.; Heilman, W.E. Wildland fire emissions, carbon and climate: Wildfire-climate interactions. For. Ecol. Manage. 2014, 317, 80-96. [CrossRef]

5. Keane, R.E.; Agee, J.K.; Fulé, P. Ecological effects of large fires on US landscapes: Benefit or catastrophe? Int. J. Wildland Fire 2008, 17, 696-712. [CrossRef]

6. Flannigan, M.A.; Cantin, S.; de Groot, W.J.; Wotton, M.; Newbery, A.; Gowman, L.M. Global wildland fire season severity in the 21st century. For. Ecol. Manage. 2013, 294, 54-61. [CrossRef]

7. Jolly, W.M.; Cochrane, M.A.; Freeborn, P.H.; Holden, Z.A.; Brown, T.J.; Williamson, G.J.; Bowman, D.M. Climate-induced variations in global wildfire danger from 1979 to 2013 . Nat. Commun. 2015, 6, 7537. [CrossRef]

8. Podschwit, H.R.; Larkin, N.K.; Steel, E.A.; Cullen, A.; Alvarado, E. Multi-Model Forecasts of Very-Large Fire Occurences during the End of the 21st Century. Climates 2018, 6, 100. [CrossRef]

9. Houghton, R.A. Aboveground Forest Biomass and the Global Carbon Balance. Glob. Chang. Biol. 2005, 11, 945-958. [CrossRef]

10. Restaino, J.C.; Peterson, D.L. Wildfire and fuel treatment effects on forest carbon dynamics in the western United States. For. Ecol. Manag. 2013, 303, 46-60. [CrossRef]

11. Hurteau, M.D.; Brooks, M.L. Short- and long-term effects of fire on carbon in us dry temperate forest systems. Biosciences 2011, 61, 139-146. [CrossRef]

12. Krawchuk, M.A.; Moritz, M.A.; Parisien, M.A.; Van Dorn, J.; Hayhoe, K. Global pyrogeography: The current and future distribution of wildfire. PLoS ONE 2009, 4, e5102. [CrossRef]

13. Fulé, P.Z.; Villanueva-Díaz, J.; Ramos-Gómez, M. Fire regime in a conservation reserve in Chihuahua, México. Can. J. For. Res. 2005, 35, 320-330. [CrossRef]

14. North, M.P.; Stephens, S.L.; Collins, B.M.; Agee, J.K.; Aplet, G.; Franklin, J.F.; Fulé, P.Z. Reform forest fire management: Agency incentives undermine policy effectiveness. Sciences 2015, 349, 1280-1281. [CrossRef] [PubMed]

15. Finney, M.A. The challenge of quantitative risk analysis for wildland fire. For. Ecol. Manage. 2005, 211, 7-108. [CrossRef]

16. Ager, A.A.; Vaillant, N.M.; Finney, M.A. A comparison of landscape fuel treatment strategies to mitigate wildland fire risk in the urban interface and preserve old forest structure. For. Ecol. Manage. 2010, 259, 1556-1570. [CrossRef]

17. Hurteau, M.; North, M. Fuel treatment effects on tree-based forest carbon storage and emissions under modeled wildfire scenarios. Front. Ecol. Environ. 2009, 7, 409-414. [CrossRef]

18. Schneider, P.; Roberts, D.A.; Kyriakidis, P.C. A VARI-based relative greenness from MODIS data for computing the fire potential index. Remote Sens. Environ. 2008, 112, 1151-1167. [CrossRef]

19. Barrio, M.; Loureiro, M.; Chasc, M.L. Aproximación a las pérdidas económicas ocasionadas a corto plazo por los incendios forestales en Galicia en 2006. Econ. Agric. Rec. Nat. 2007, 7, 45-64. [CrossRef]

20. Barreal, J.; Loureiro, M.L. Modelling spatial patterns and temporal trends of wildfires in Galicia (NW Spain). For. Syst. 2015, 24, e022. 
21. Mavsar, R.; González-Cabán, A.; Varela, E. The State of Development of Fire Management Decision Support Systems in America and Europe. For. Policy Econ. 2013, 29, 45-55. [CrossRef]

22. Rodríguez y Silva, F.; Molina Martínez, J.R.; González-Cabán, A. A Methodology for Determining Operational Priorities for Prevention and Suppression of Wildland Fires. Int. J. Wildl. Fire 2014, 24, 544-554. [CrossRef]

23. Ottmar, R.D.; Sandberg, D.V.; Riccardi, C.L.; Prichard, S.J. An overview of the fuel characteristic classification system-Quantifying, classifying, and creating fuelbeds for resource planning. Can. J. For. Res. 2007, 37, 2383-2393. [CrossRef]

24. Boer, M.; Sadler, R.; Wittkuhn, R.; McCaw, L.; Grierson, P. Long-term impacts of prescribed burning on regional extent and incidence of wildfires-evidence from 50 years of active fire management in SW Australian forests. For. Ecol. Manag. 2009, 259, 132-142. [CrossRef]

25. Chuvieco, E.; Aguado, I.; Yebra, M.; Nieto, H.; Salas, J.; Martín, M.P.; Vilar, L.; Martínez, J.; Martín, S.; Ibarra, P.; et al. Development of a framework for fire risk assessment using remote sensing and geographic information system technologies. Ecol. Model. 2010, 221, 46-58. [CrossRef]

26. Wang, A.Y.B.; Anderson, K.R. An evaluation of spatial and temporal patterns of lightning- and human-caused forest fires in Alberta, Canada, 1980-2007. Int. J. Wildl. Fire 2010, 19, 1059-1072. [CrossRef]

27. Ordóñez, C.; Saavedra, A.; Rodríguez-Pérez, J.R.; Castedo-Dorado, F.; Covián, E. Using model-based zeostatistics to predict lightning-caused wildfires. Environ. Model. Softw. 2012, 29, 44-50. [CrossRef]

28. Parisien, M.A.; Parks, S.A.; Krawchuk, M.A.; Little, J.M.; Flannigan, M.D.; Gowman, L.M.; Moritz, M.A. An analysis of controls on fire activity in boreal Canada: Comparing models built with different temporal resolutions. Ecol. Appl. 2014, 24, 1341-1356. [CrossRef]

29. Nunes, M.C.S.; Vasconcelos, M.J.; Pereira, J.M.C.; Dasgupta, N.; Alldredge, R.J.; Rego, F.J. Land cover type and fire in Portugal: Do fires burn land cover selectively? Landsc. Ecol. 2005, 20, 661-673. [CrossRef]

30. Moreira, F.; Vaz, P.; Catry, F.; Silva, J.S. Regional variations in wildfire susceptibility of land-cover types in Portugal: Implications for landscape management to minimize fire hazard. Int. J. Wildl. Fire 2009, 18, 563-574. [CrossRef]

31. Dlamini, W.M. A Bayesian belief network analysis of factors influencing wildfire occurrence in Swaziland. Environ. Model. Soft. 2010, 25, 199-208. [CrossRef]

32. Ager, A.A.; Preisler, H.K.; Arca, B.; Spano, D.; Salis, M. Wildfire Risk Estimation In The Mediterranean Area. Environmetrics 2014, 25, 384-396. [CrossRef]

33. Chang, Y.; Zhu, Z.L.; Bu, R.C.; Chen, H.W.; Feng, Y.T.; Li, Y.H.; Hu, Y.M.; Wang, Z.C. Predicting fire occurrence patterns with logistic regression in Heilongjiang Province, China. Landsc. Ecol. 2013, 28, 1989-2004. [CrossRef]

34. Natario, I.; Oliveira, M.M.; Marques, S. Using INLA to Estimate a Highly Dimensional Spatial Model for Forest Fires in Portugal. In New Advances in Statistical Modeling and Applications, Studies in Theoretical and Applied Statistics; Pacheco, A.R., Oliveira, M.d.R., Paulino, C.D., Eds.; Springer International Publishing: Basel, Switzerland, 2014; p. 239.

35. Archibald, S.; Roy, D.P.; van Wilgen, B.W.; Scholes, R.J. What limits fire? An examination of drivers of burnt area in Southern Africa. Glob. Chang. Biol. 2009, 15, 613-630. [CrossRef]

36. Kahiu, M.N.; Hanan, N.P. Fire in subSaharan Africa: The fuel, cure and connectivity hypothesis. Glob. Ecol. Biogeogr. 2017, 2018, 1-12. [CrossRef]

37. Marques, S.; Garcia-Gonzalo, J.; Botequim, B.; Ricardo, A.; Borges, J.G.; Tomé, M.; Oliveira, M.M. Assessing wildfire occurrence probability in Pinus pinaster Ait. stands in Portugal. For. Syst. 2012, 21, 111-120. [CrossRef]

38. Gonzalez, J.R.; Palaí, M.; Pukkala, T. A fire probability model for forest stands in Catalonia (northeast Spain). Ann. For. Sci. 2006, 63, 1-8. [CrossRef]

39. Fernandes, P.M.; Loureiro, C.; Magalhães, M.; Ferreira, P.; Fernandes, M. Fuel age, weather and burn probability in Portugal. Int. J. Wildl. Fire 2012, 21, 380-384. [CrossRef]

40. Botequim, B.; Garcia-Gonzalo, J.; Marques, S.; Ricardo, A.; Borges, J.G.; Tomé, M.; Oliveira, M.M. Developing wildfire risk probability models for Eucalyptus globulus stands in Portugal. iForest 2013, 6, 217-227. [CrossRef]

41. Krawchuk, M.; Moritz, M. Constraints on global fire activity vary across a resource gradient. Ecology 2011, 92, 121-132. [CrossRef] 
42. Bradstock, R.A. A biogeographic model of fire regimes in Australia: Current and future implications. Glob. Ecol. Biogeogr. 2010, 19, 145-158. [CrossRef]

43. Holz, A.; Kitzberger, T.; Paritsis, J.; Veblen, T.T. Ecological and climatic controls of modern wildfire activity patterns across southwestern South America. Ecosphere 2012, 3, 103. [CrossRef]

44. Westerling, A.L.; Gershunov, A.; Brown, T.J.; Cayan, D.R.; Dettinger, M.D. Climate and wildfire in the western United States. Bull. Am. Meteorol. Soc. 2003, 84, 595-604. [CrossRef]

45. Meyn, A.; White, P.S.; Buhk, C.; Jentsch, A. Environmental drivers of large, infrequent wildfires: The emerging conceptual model. Progr. Phys. Geogr. 2007, 31, 287-312. [CrossRef]

46. Sherriff, R.L.; Veblen, T.T. Variability in fire-climate relationships in ponderosa pine forests in the Colorado Front Range. Int. J. Wildland Fire 2008, 17, 50-59. [CrossRef]

47. Littell, J.S.; McKenzie, D.; Peterson, D.L.; Westerling, A.L. Climate and wildfire area burned in western US ecoprovinces, 1916-2003. Ecol. Appl. 2009, 19, 1003-1021. [CrossRef]

48. Pausas, J.G.; Ribeiro, E. Fire and productivity. Glob. Ecol. Biogeogr. 2013, 22, 728-736. [CrossRef]

49. Kahiu, M.N.; Hanan, N.P. Estimation of woody and herbaceous leaf area index in sub-Saharan Africa using Modis data. J. Geophys. Res. Biogeosci. 2017, 123, 3-17. [CrossRef]

50. Chuvieco, E.; Giglio, L.; Justice, C. Global characterization of fire activity: Toward defining fire regimes from Earth observation data. Glob. Chang. Biol. 2008, 14, 1488-1502. [CrossRef]

51. INEGI (Instituto Nacional de Estadística y Geografía-México). Guía Para la Interpretación de Cartografía: Uso del suelo y Vegetación. escala 1, 250, 000: Serie V; Instituto Nacional de Estadística y Geografía: Ciudad de México, México, 2011.

52. Rodríguez-Trejo, D.A. Fire regimes, fire ecology and fire management in México. AMBIO A J. Hum. Environ. 2008, 377, 548-556. [CrossRef]

53. Rodríguez-Trejo, D.A. Incendios de Vegetación: Su Ecología, Manejo e Historia. México; Colegio de Post Graduados: Chapingo, Mexico, 2015; p. 814. (In Spanish)

54. Jardel-Peláez, E.J.; Alvarado, E.; Quintero-Gradilla, S.D.; Rodríguez-Gómez, J.M.; Pérez-Salicrup, D.; Michel-Fuentes, J.M.; Morfín-Ríos, J.E.; Castillo-Navarro, M.F. Fuel beds and fire potential in Mexican terrestrial ecosystems. Fire Ecol. 2019. under review.

55. Manzo-Delgado, L.; Sánchez-Colón, S.; Álvarez, R. Assessment of seasonal forest fire risk using NOAA-AVHRR: A case study in central Mexico. Int. J. Remote Sens. 2009, 30, 4991-5013. [CrossRef]

56. Avila-Flores, D.; Pompa-Garcia, M.; Antonio-Nemiga, X.; Rodriguez-Trejo, D.; Vargas-Perez, E.; Santillan-Perez, J. Driving factors for forest fire occurrence in Durango State of Mexico: A geospatial perspective. Chin. Geo. Sci. 2010, 20, 491-497. [CrossRef]

57. Avila-Flores, D.Y.; Pompa-Garcia, M.; Vargas, P.E. Spatial analysis of fire occurrence in the Durango state. Revista Chapingo Serie Ciencias Forestales 2010, 16, 253-260.

58. Zuñiga-Vazquez, J.M.; Pompa-Garcia, M. The occurrence of forest fires in Mexico presents an altitudinal tendency: A geospatial analysis. Nat. Hazards 2018, 1-12, 2018. [CrossRef]

59. Cartus, O.; Kellndorfer, J.; Walker, W.; Franco, C.; Bishop, J.; Santos, L.; Fuentes, J.M.M. A National, Detailed Map of Forest Aboveground Carbon Stocks in Mexico. Remote Sens. 2014, 6, 5559-5588. [CrossRef]

60. Rodriguez-Veiga, P.; Saatchi, S.; Tansey, K.; Balzter, H. Magnitude, spatial distribution and uncertainty of forest biomass stocks in Mexico. Remote Sens. Environ. 2016, 183, 265-281. [CrossRef]

61. Lopez-Serrano, P.M.; Lopez-Sanchez, C.A.; Diaz-Varela, R.A.; Corral-Rivas, J.J.; Solis-Moreno, R.; Vargas-Larreta, B.; Alvarez-Gonzalez, J.G. Estimating biomass of mixed and uneven-aged forests using spectral data and a hybrid model combining regression trees and linear models. iForest 2015, 9, 226-234. [CrossRef]

62. López-Serrano, P.M.; López-Sánchez, C.A.; Solís-Moreno, R.; Corral-Rivas, J.J. Geospatial estimation of above ground forest biomass in the Sierra Madre Occidental in the state of Durango, Mexico. Forest 2016, 7, 70. [CrossRef]

63. López-Serrano, P.M.; Corral-Rivas, J.J.; Díaz-Varela, R.A.; Álvarez-González, J.G.; López-Sánchez, C.A. Evaluation Of Radiometric And Atmospheric Correction Algorithms For Aboveground Forest Biomass Estimation Using Landsat-5 Tm. Data. Remote Sens. 2016, 8, 396. [CrossRef]

64. López-Serrano, P.M.; López-Sánchez, C.A.; Álvarez-González, J.G.; García-Gutiérrez, J. A comparison of machine learning techniques applied to landsat- $5 \mathrm{tm}$ spectral data for biomass estimation. Can. J. Remote Sens. 2016, 42, 690-705. [CrossRef] 
65. Lee, B.S. The Canadian Wildland Fire Information System. In Proceedings of the 9th Annual Conference on Geographic Information Systems in Forestry, Vancouver, BC, Canada, 27 March 1995; GIS World Inc.: Fort Collins, CO, USA; pp. 639-646.

66. Burgan, R.E.; Andrews, P.L.; Bradshaw, L.S.; Chase, C.H.; Hartford, R.A.; Latham, D.J. WFAS: Wildland fire assessment system. Fire Manag. Notes 1997, 57, 4-17.

67. Jolly, W.M.; Andrews, P.L.; Bradshaw, L.S. The Wildland Fire Assessment System (WFAS): A webbased resource for decision support. In Proceedings of the EastFire Conference, Virginia, Fairfax, VA, USA, 11-13 May 2005; George Mason University: Fairfax, VI, USA.

68. Preisler, H.K.; Burgan, R.E.; Eidenshink, J.C.; Klaver, J.M.; Klaver, R.W. Forecasting Distributions of Large Federal-Lands Fires Utilizing Satellite and Gridded Weather Information. Int. J. Wildl. Fire 2009, 18, 508-516. [CrossRef]

69. Jolly, W.M.; Freeborn, P.H. Towards Improving Wildland Firefighter Situational Awareness Through Daily Fire Behaviour Risk Assessments In The US Northern Rockies And Northern Great Basin. Int. J. Wildl. Fire 2017, 26, 574-586. [CrossRef]

70. Vega-Nieva, D.; Nava-Miranda, M.G.; Calleros-Flores, E.; Lopez-Serrano, P.M.; Briseño-Reyes, J.; Lopez-Sanchez, C.A.; Flores-Medina, F.; Corral-Rivas, J.J.; Gonzalez-Caban, A.; Alvarado-Celestino, E. Developing a Forest Fire Danger System for Mexico. In Proceedings of the Fifth International Symposium on Fire Economics, Planning, and Policy: Ecosystem Services and Wildfires, Tegucigalpa, Honduras, 14-18 November 2016; González-Cabán, A., Sánchez, J.J., USDA Forest Service, Pacific Southwest Research Station, Eds.; General Technical Report PSW-GTR-261. 2019. Available online: https://www.fs.usda.gov/treesearch/pubs/57665 (accessed on 6 May 2019).

71. Vega-Nieva, D.J.; Monjarás-Vega, N.; Briones-Herrera, C.I.; Briseño-Reyes, J.; Nava-Miranda, M.G.; Calleros-Flores, E.; Flores-Medina, F.; López-Serrano, P.M.; Corral-Rivas, J.J.; Cruz-López, M.I.; et al. El Sistema de Predicción de Peligro de incendios forestales para México. [The Fire Danger Prediction System of Mexico]. Expo Forestal 2018. Guadalajara. 11 October 2018. Available online: http://forestales.ujed.mx/ incendios/incendios/pdf/Vega18_SistemaPeligro_ExpoGuadalajara_11Oct2018.pdf (accessed on 6 May 2019).

72. Vega-Nieva, D.J.; Briseño-Reyes, J.; Nava-Miranda, M.G.; Calleros-Flores, E.; López-Serrano, P.M.; Corral-Rivas, J.J.; Montiel-Antuna, E.; Cruz-López, M.I.; Cuahutle, M.; Ressl, R.; et al. Developing Models to Predict the Number of Fire Hotspots from an Accumulated Fuel Dryness Index by Vegetation Type and Region in Mexico. Forests 2018, 9, 190. [CrossRef]

73. Vega-Nieva, D.J.; Nava-Miranda, M.G.; Calleros-Flores, E.; López-Serrano, P.M.; Briseño-Reyes, J.; Corral-Rivas, J.J.; Cruz-López, M.I.; Cuahutle, M.; Ressl, R.; Alvarado-Celestino, E.; et al. Temporal patterns of fire density by vegetation type and region in Mexico and its temporal relationships with a monthly satellite fuel greenness index. Fire Ecol. 2019. under review.

74. Vega-Nieva, D.J.; Nava-Miranda, M.G.; López-Serrano, P.M.; Briseño-Reyes, J.; Corral-Rivas, J.J.; Cruz-López, M.I.; Cuahutle, M.; Ressl, R.; Alvarado-Celestino, E.; González-Cabán, A. Modeling the internannual and monthly variations in the spatial distribution of active fires from a fuel dryness index by vegetation type and region in Mexico. PLoS ONE 2019. under review.

75. Pompa-García, M.; Camarero, J.J.; Rodríguez-Trejo, D.A.; Vega-Nieva, D.J. Drought and spatio temporal variability of forest fires across Mexico. Chin. Geo. Sci. 2017, 28, 25-37. [CrossRef]

76. ERDAS Inc. ERDAS IMAGINE 2014. Available online: Http://www.hexagongeospatial.com/products/ ERDAS-IMAGINE/details.aspx (accessed on 27 March 2019).

77. ESRI. ArcGIS Desktop 10.1; Environmental Systems Research Institute: Redlands, CA, USA, 2011.

78. Weibul, L.W. Statistical distribution function of wide applicability. J. App. Mechs. 1951, 18, $292-297$.

79. Grissino-Mayer, H.D. Modeling Fire Interval Data from the American Southwest with the Weibull Distribution. Int. J. Wildland Fire 1999, 9, 37-50. [CrossRef]

80. Polakow, D.; Dunne, T. Modelling fire return interval T: Stochasticity and censoring in the two- parameter Weibull model. Ecol. Modell. 1999, 121, 79-102. [CrossRef]

81. Rennolls, K.; Geary, D.N.; Rollison, T.J.D. Characterizing diameter distributions by the use of the Weibull distribution. Forestry 1985, 58, 57-66. [CrossRef]

82. Maltamo, M.; Puumalainen, J.; Päivinen, R. Comparison of beta and Weibull functions for modelling basal area diameter distribution in stands of Pinus sylvestris and Picea abies. Scand. J. For. Res. 1995, 10, $284-295$. [CrossRef] 
83. Nanang, D.M. Suitability of the Normal, Log-Normal and Weibull distributions for fitting diameter distributions of neem plantations in Northern Ghana. For. Ecol. Manag. 1998, 103, 1-7. [CrossRef]

84. R Core Team. R: A Language and Environment for Statistical Computing; R Foundation for Statistical Computing: Vienna, Austria; Available online: https://www.R-project.org/ (accessed on 20 March 2017).

85. Bates, D.M.; Watts, D.G. Nonlinear Regression Analysis and its Applications; John Wiley \& Sons: New York, NY, USA, 1988.

86. Zhang, L.; Peng, L.; Huang, S.; Zhou, X. Development and evaluation of ecoregion-based tree height-diameter models for jack pine in Ontario. For. Chron. 2002, 78, 530-538. [CrossRef]

87. Castedo, F.; Barrio, M.; Parresol, B.R.; Álvarez González, J.G. A stochastic height-diameter model for maritime pine ecoregions in Galicia (northwestern Spain). Ann. For. Sci. 2005, 62, 455-465. [CrossRef]

88. Corral-Rivas, J.J.; Barrio-Anta, M.; Treviño-Garza, E.; Diéguez-Aranda, U. Use of stump diameter to estimate diameter at breast height and tree volume, for major pine species in El Salto, Durango (Mexico). Forestry 2007, 80, 29-40. [CrossRef]

89. Lilliefors, H.W. On the Kolmogorov-Smirnov test for the exponential distribution with mean unknown. J. Am. Stat. Assoc. 1969, 64, 387-389. [CrossRef]

90. Reynolds, M.R.; Burk, T.E.; Huang, W. Goodness-of-fit tests and model selection procedures for diameter distributions models. For. Sci. 1988, 34, 377-399.

91. González-Ferreiro, E.; Arellano-Pérez, S.; Castedo-Dorado, F.; Hevia, A.; Vega, J.A.; Vega-Nieva, D.; Álvarez-González, J.G.; Ruiz-González, A.D. Modelling the vertical distribution of canopy fuel load using national forest inventory and low-density airbone laser scanning data. PLoS ONE 2017, 12, e0176114. [CrossRef]

92. Ryan, T.P. Modern Regression Methods. In Wiley Series in Probability and Statistics; John Wile and Sons: New York, NY, USA, 1997; 515p.

93. Hui, G.Y.; Gadow, K. v. Zur Entwicklung von Einheitshöhenkurven am Beispiel der Baumart Cunninghamia lanceolata. Allg.Forst- u. Jagdztg 1993, 164, 218-220.

94. Minnich, R.A.; Chou, Y.H. Wildland fire patch dynamics in the chaparral of southern California and Northern Baja California. Int. J. Wildl. Fire 1997, 7, 221-248. [CrossRef]

95. Regelbrugge, J.C.; Conard, S.G. Biomass and Fuel Characteristics of Chaparral in Southern California. In Proceedings of the 13th Conference on Fire and Forest Meteorology, Lorne, Australia, 27-31 October 1996.

96. Schmidt, I.T.; O'Leary, J.F.; DouStow, D.A.; Uyeda, K.A.; Riggan, P.J. Use of ultra-high spatial resolution aerial imagery in the estimation of chaparral wildfire fuel loads. Environ. Monit. Assess. 2016, 188, 697. [CrossRef]

97. Anderson, W.R.; Cruz, M.G.; Fernandes, P.M.; McCaw, W.L.; Vega, J.A.; Bradstock, R.A.; Fogarty, L.; Gould, J.; McCarthy, G.; Marsden-Smedley, J.B.; et al. A generic, empirical-based model for predicting rate of fire spread in shrublands. Int. J. Wildl. Fire 2015, 24, 443-460. [CrossRef]

98. Baeza, M.J.; Raventós, J.; Escarré, A.; Vallejo, V.R. Fire risk and vegetation structural dynamics in Mediterranean shrubland. Plant Ecol. 2006, 187, 189-201. [CrossRef]

99. Baeza, J.; Santana, V.M.; Pausas, J.G.; Vallejo, R. Successional trends in standing dead biomass in Mediterranean Basin species. Sci. J. Veg. Sci. 2011, 22, 467-474. [CrossRef]

100. Pausas, J.G.; Bradstock, R.A. Fire persistence traits of plants along a productivity and disturbance gradient in mediterranean shrublands of southeast Australia. Glob. Ecol. Biogeogr. 2007, 16, 330-340. [CrossRef]

101. Oliveira, S.; Moreira, F.; Boca, R.; San-Miguel-Ayanz, J.; Pereira, J.M.C. Assessment of fire selectivity in relation to land cover and topography: A comparison between Southern European countries. Int. J. Wildl. Fire 2013, 23, 620-630. [CrossRef]

102. Monjarás-Vega, N.A.; Vega-Nieva, D.J.; Briones-Herrera, C.I.; Flores-Medina, F.; Calleros-Flores, E.; Corral-Rivas, J.J.; López-Serrano, P.M.; Pompa-García, M.; Alvarado, E.; González-Cabán, A.; et al. Modeling and mapping fire risk from human factors in Mexico. In Proceedings of the 6th International Fire Behavior and Fuels Conference, Albuquerque, NM, USA, 29 April-3 May 2019.

103. Syphard, A.D.; Brennan, T.J.; Keeley, J.E. Chaparral landscape conversion in southern California. In Valuing Chaparral; Underwood, E.C., Safford, H.D., Molinari, N.A., Keeley, J.E., Eds.; Springer International Publishing: Basel, Switzerland, 2018; pp. 311-334.

104. Archibald, S.; Staver, A.C.; Levin, S.A. Evolution of human driven fire regimes in Africa. Proc. Natl. Acad. Sci. USA 2012, 109, 847-852. [CrossRef] 
105. Cortés-Montaño, C.; Fulé, P.Z.; Falk, D.A.; Villanueva-Díaz, J.; Yocom, L.L. Linking old-growth forest composition, structure, fire history, climate and land-use in the mountains of northern México. Ecosphere 2012, 3, 106. [CrossRef]

106. Fulé, P.Z.; Waltz, A.E.M.; Covington, W.W.; Heinlein, T.A. Measuring forest restoration effectiveness in reducing hazardous fuels. J. For. 2001, 99, 24-29.

107. Kaufmann, M.R.; Binkley, D.; Fulé, P.Z.; Johnson, M.; Stephens, S.L.; Swetnam, T.W. Defining old growth for fire-adapted forests of the western United States. Ecol. Soc. 2007, 12, 15. [CrossRef]

108. Cochrane, M.A. Fire science for rainforests. Nature 2003, 421, 913-919. [CrossRef] [PubMed]

109. Román-Cuesta, R.M.; Retana, J.; Gracia, M. Fire trends in tropical Mexico: A case study of Chiapas. J. For. 2004, 102, 26-48.

110. Rodríguez-Trejo, D.A.; Tchikoué, H.; Cíntora, C.; Contreras, R.; de la Rosa, A. Combustibles forestales, peligro de incendio y áreas prioritarias de protección en las zonas afectadas por el huracán Dean. Agrociencia 2011, 45, 593-608.

111. Ressl, R.; Lopez, G.; Cruz, I.; Colditz, R.R.; Schmidt, M.; Ressl, S.; Jiménez, R. Operational active fire mapping and burnt area identification applicable to Mexican Nature Protection Areas using MODIS and NOAA-AVHRR direct readout data. Remote Sens. Environ. 2009, 113, 1113-1126. [CrossRef]

112. Dohn, J.; Dembele, F.; Karembe, M.; Moustakas, A.; Amevor, K.A.; Hanan, N.P. Tree effects on grass growth in savannas: Competition, facilitation and the stress-gradient hypothesis. J. Ecol. 2013, 101, 202-209. [CrossRef]

113. Verschuyl, J.; Clark, L.; Loehle, C. Predicting Shrub Biomass and Current Annual Growth from Field Measurements in the Oregon Coast Range. Northw. Sci. 2018, 92, 9-17. [CrossRef]

114. Flores-Medina, F.; Vega-Nieva, D.J.; Monjarás-Vega, N.; Briones-Herrera, C.I.; Corral-Rivas, J.J.; Calleros, E.; López-Serrano, P.M.; Alvarado, E.; González-Cabán, A.; Pérez-Salicrup, D.; et al. Mapping fuel loads and fire behavior from Sentinel in Durango, NW Mexico. In Proceedings of the 6th International Fire Behavior and Fuels Conference, Albuquerque, NM, USA, 29 April-3 May 2019.

(C) 2019 by the authors. Licensee MDPI, Basel, Switzerland. This article is an open access article distributed under the terms and conditions of the Creative Commons Attribution (CC BY) license (http://creativecommons.org/licenses/by/4.0/). 